\title{
LAND PLOTS VALUATION IN LAND CONSOLIDATION IN SLOVAKIA: A NEED FOR A NEW APPROACH
}

\author{
Zlatica MUCHOVÁ ${ }^{1,}$, Lubomír KONC ${ }^{1}$, František PETROVIČ ${ }^{2}$ \\ ${ }^{1}$ Department of Landscape Planning and Land Consolidation, Slovak University of Agriculture in Nitra, \\ Nitra, Slovak Republic \\ ${ }^{2}$ Department of Ecology and Environmental Sciences, Constantine the Philosopher University in Nitra, \\ Nitra, Slovak Republic
}

Received 7 January 2017; accepted 31 October 2017

\begin{abstract}
The spatial and functional rearrangement of a territory in the process of land consolidation (LC) requires the prior valuation of the land and comparison with the proposed state. This is one of the most difficult stages of the project. The official (information) price of agricultural land is at present determined on the basis of comparing the boundaries of land areas and spatial distribution of the soil-quality ecological units (SQEU). This procedure does not reflect the real value of land and leads to disagreements particularly with large differences in price levels in the neighborhood. Therefore, the authors suggest establishing pricing information using a multicriteria evaluation, into which enters SQEU (through a single price area for the projection unit) as well as the development factor and location factor. The methodological approaches and procedures for land valuation on agricultural land in the LC are illustrated by the example of the cadastral area of Skačany (in northwestern Slovakia). The authors argue that a new approach is more objective to the owners and simplifies the entire process in compliance with the criteria of proportionality.
\end{abstract}

Keywords: land ownership, land value, official price of agricultural land, multi-criteria evaluation of property value, spatial and functional rearrangement of a territory.

\section{Introduction}

Land consolidation (LC) is a tool to achieve such a functional arrangement of territory to enable each landowner to dispose of their property, while respecting the principles of protection and the development of the landscape, the soil potential and other environmental components. The basic principle of land redistribution according to FAO (2003) is that each landowner shall be granted a property of an aggregate value that is the same (after deducting the landowners' land contribution for infrastructure) as the value of the property owned prior to consolidation. The landowners have to be compensated for the value of their land and permanent crops in LC (Tanentzap, Lamb, Walker, \& Farmer, 2015). In general, each land owner shall get land, so that the value of the land transferred is equal to the value of the land obtained (Lisec, Primožič, Ferlan, Šumrada, \& Drobne, 2014). One of the fundamental principles of LC is that each participant has to get a rounded property with an equal area, and the same or very similar soil quality as the given land. As a rule, land valuation is the key and the most demanding operation of the entire LC procedure (Branković, Parezanović, \& Simović, 2015).

The objective of land valuation is to facilitate the LC (re-allotment) process through establishing a platform for the formation of the land prices that can be commonly accepted by the participants (Hartvigsen, 2014). Traditionally we distinguish two valuation methods A) using a market price and B) official price. While the market price is largely regulated and affected by the land market itself (the offer of so-called free land and the demand for it), the official price is strictly defined by legal instruments. Slovak legislation for the LC process does not work with the market price. Only the so-called official price is compiled, which is regarded as a relative value or "an information price" comparing/relating the state before and after the LC project. Plots after a re-allotment have to be equivalent (as the Slovak legislation mandates and owners expect) to those before also in terms of value that is expressed by the information price. In this sense the price is per-

*Corresponding author. E-mail: zlatica.muchova@gmail.com 
ceived as real. This (rather low) price is also used for the state purchase of land (small plots of less than $400 \mathrm{~m}^{2}$ of agricultural and $2000 \mathrm{~m}^{2}$ of forest land) from the owners throughout the entire LC process and as a base for compensation of net loss of land in infrastructure and industrial construction. In any case, this is not the price of the land in terms of trade relations. According to Buday and Vilček (2013), no mechanism exists for this value (state regulatory office price) to be transformed into a market price. A lot of facts influence the price of a certain fixed asset (Kertscher, 2003). E.g. according to Lisec and Pintar (2005), the assessment of agricultural land and forestry is based on the natural productive capacity while the market valuation methods are usually used for infrastructure and buildings. E.g. Hartvigsen (2014) speaks about the creation of relative value for accounting based on: recent transactions in or around the area, existing soil maps, register values (for land tax purposes), land use plans (territorial planning), price expectations from both potential sellers and buyers. Branković et al. (2015) conclude that, the land valuation entails an approximate land valuation that determines the number of valuation grades (classes), their relations and a detailed land valuation that classifies individual plots in the established valuation grades. Classification of all plots in the valuation grades can be performed according to soil fertility, climate conditions, and economic factors with the method called the "nominal land valuation method", Yomralioglu, Nisanci, and Yildirim (2007). This method uses the same price of land for a given unit area that is reflected in all the real estate that can be found there. The method uses a parametric way instead of a definite value. Selected objective and subjective criteria are evaluated one by one. Valuation of plots is thus a very complex task due to accounting for characteristics of the plot themselves, but also numerous neighborhood conditions and other factors bearing upon their value (Yomralioglu \& Nisanci, 2004).

The basis for the determination of land prices in Slovakia (SR) is the intersection of land boundaries layer with a price map. The price map represents the area of spatial distribution of the soil-quality ecological units (SQEU) described by a 7-digit code and their assigned tariffs for agricultural land (including arable soil, permanent grasslands, vineyards, hop gardens, orchards, gardens) and the tariff rates for other areas (including water surfaces, builtup areas, forests and other places) in $€$ per $\mathrm{m}^{2}$. The price list is according to the SQEU 7-digit code published in the Decree No. 38/2005 Coll. The rate for agricultural land can range from 0.022 to $0.402 € / \mathrm{m}^{2}$ and from 0.017 to $0.302 € / \mathrm{m}^{2}$ in other cases. The soil quality valuation system currently contains 7140 SQEU (Stredanská, Muchová, \& Konc, 2013). In its 7-digit code there are embedded specific properties (stable characters) of a certain SQEU area expressing the appropriate combination of the 11 categories of climatic regions, 100 major soil units, 6 categories of slopes, 4 categories of exposure, 4 categories of stoniness (grittiness), 3 categories of soil depth and 5 categories of particle size.
Experience shows that prices derived from SQEU present in the area do not reflect the true value of the land, see e.g. Bujnovský, Balkovič, Barančíková, and Vilček (2009), Buday (2012), Buday and Vilček (2013); Muchová, Stredanská, and Konc (2014). Current way of the valuation of the land in Slovakia, leads to controversy especially in those cases where the owners are placed in locations with a significant difference between two neighboring SQEU prices. Demetriou (2016) also highlights the perception/ objections by landowners who usually compare the land value assigned to their land parcels with other similar or adjacent plots using their own experience and not the official process.

Grausová and Buday (2016) argue that it is necessary to objectively determine land prices and, in particular, take into account other factors that greatly influence the price of land. One important factor influencing the price of land is its location on the border of the residential and rural areas of a city or municipality. An important group of factors affecting the price of land consists of anthropogenic factors, with different restrictions reducing the price of land. This is mainly in the territories as national parks, protected landscape areas, and zones for water resources protection. Furthermore, there are a variety of restrictions on farming techniques, especially in the use of fertilizers and chemical protection, which have resulted in a reduction of agricultural yields or there are areas affected by industrial emissions/contamination thus reducing the price and quality of agricultural crops. According to Konc (2012), an important group of factors influencing the price of land consists of transportation access that is linked to the land management of remote and elevated land.

Some of the above mentioned factors are too complex to be included into land valuation for LC and too detailed for the desired outcomes. However, at the same time, authors do agree with Buday (2012) that there is a need to propose a new system of land valuation that takes into account a properly/correctly selected factors, whose values or quality strongly influence given area. It might be interesting to reevaluate the current state of SQEU based land valuation for LC in Slovakia and find an approach that would more realistically reflect the benefits of a specific location.

The aim of this work is to propose a new approach for setting the relative/official/informative price of land through a multicriteria evaluation system. A number of criteria having a significant influence on the final price of land are defined. Methodology and procedures for land valuation within LC are designed.

\section{Material and methods}

The present procedure is the adaptation of valid legislation in the LC process and methodical guidelines with the use of the area prices set out therein. Some other important legislative and methodological regulations include:

- Act No. 330/1991 Coll. on land consolidation, arrangements of land ownership, land offices, land fund and about land associations, as amended. 
- Methodical instructions to perform geodetic activities for the land consolidation project (Vanek et al., 2008).

- Decree No. 38/2005 Coll. on the determination of the value of land and crops for the purpose of land consolidation.

\subsection{The new proposal foresees}

- No changes in legislation and methods of LC with the exception of the slight reordering of individual processing stages of LC projects.

- The valuation of forests remains the same.

- Preserving the principle of the price maps.

- Taking into account practical experience in the form of coefficients to be determined on the basis of local knowledge.

- Taking account of land development in the LC perimeter based on the municipality land plan or intentions on the basis of discussions with the local council.

- Avoiding disproportions caused by SQEU borders within soil units.

\subsection{Steps}

- Area from the cadastral territory of Skačany is introduced as a test case.

- Calculation of areas of prices in a currently valid manner and valuation of model plots.

- Proposal for the differentiation of land according to expected development as well as historical and social impacts with the aim of the involvement of owners and their local knowledge to determine plot prices.

- Proposal for a new valuation principle through the application of multicriteria methods.

a)

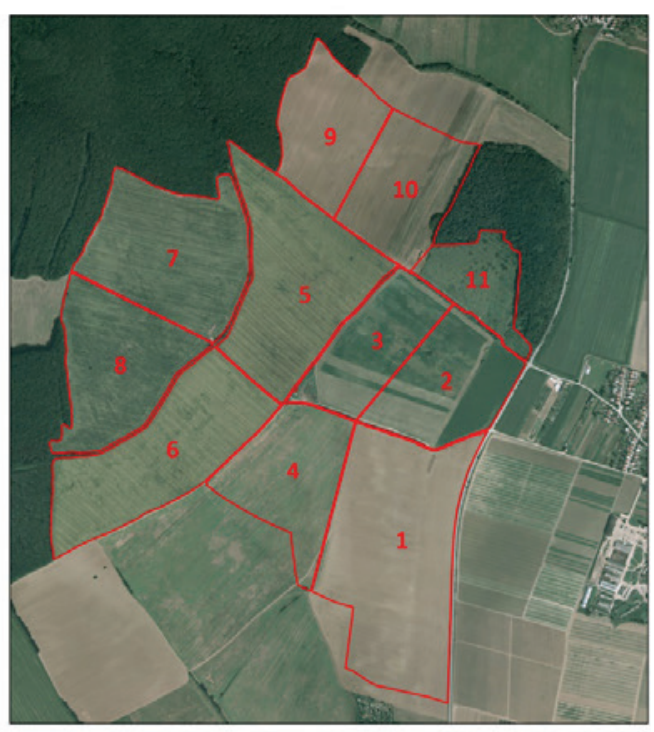

Caption

ortho-photo-map of the cadastral territory Skačany

boundaries of selected soil areas

numeric designation of selected soil areas
- Verification of a new methodological procedure on an example and comparison with the current procedure.

\subsection{Case study}

Test cases for land valuation are plots in the LC project perimeter in the administrative area of Skačany. Skačany municipality is located in the northern part of the Partizánske district, Trenčín Region, in northwestern Slovakia. To illustrate the results a section consisting of 11 soil units was used. Intensively agriculturally cultivated areas (large chunks of arable land) with different types of cultivated crops (sown corn, perennial clover, winter wheat) have been selected. The distance of the area to a settlement is $1-5 \mathrm{~km}$.

No construction/development was foreseen in the area. In the medium term, in terms of municipality development, the site near the forest in the northeastern part of the presented area is considered for recreational use. (soil unit 11). Field unit 1 is considered more valuable due to best access. Valuation of forest land (using an expert estimate) will not be dealt with. Location and parameters of the selected soil units are presented in Figures $1 \mathrm{a}$ and $1 \mathrm{~b}$.

The municipality lies in the north (i.e. Bánovce) spur of the Nitra loess hills on the southern edge of the Strážovské hills on the left side of the Nitrica River. The area of the whole cadaster is $15.37 \mathrm{~km}^{2}$, of which about half (54\%) occupies agricultural land. The altitude in the middle of the municipality is $208 \mathrm{~m}$ a.s.l., the territory lying within a range from 196 to $432 \mathrm{~m}$ a.s.l. (Figure 2b). Slope reliefs of $3-7^{\circ}$ (Figure $2 \mathrm{a}$ ) prevail. It is dominated by a combination of exposure to the south to east and west exposure (Figure 2c). The area is sufficiently warm, dry, upland. There are various representative subtypes of fluvial soil,

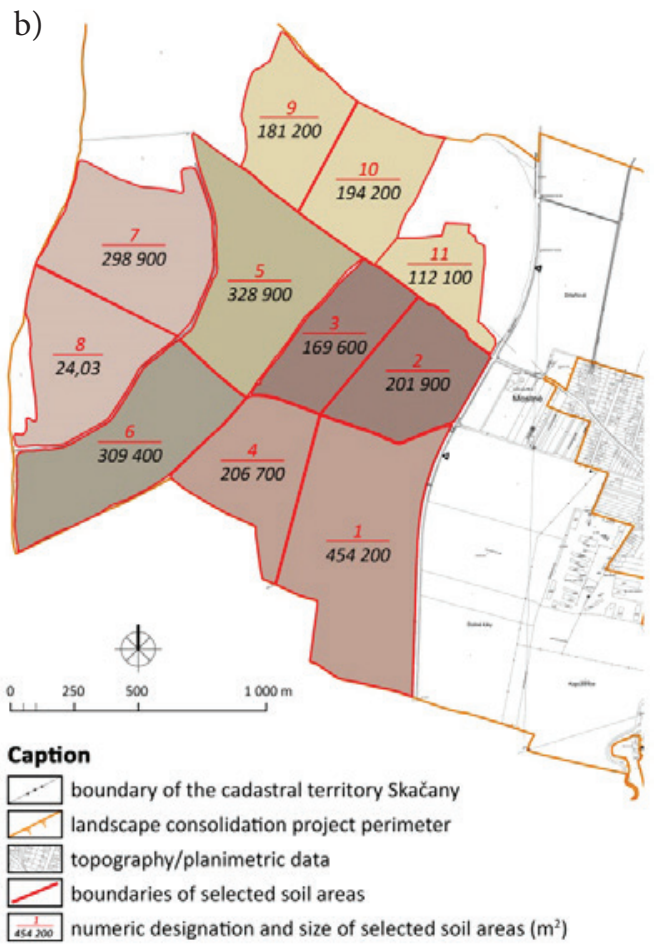

Figure 1. a) Soil units on the orthophotomap background (underlay Eurosense, 2014), b) Parametres of soil units 

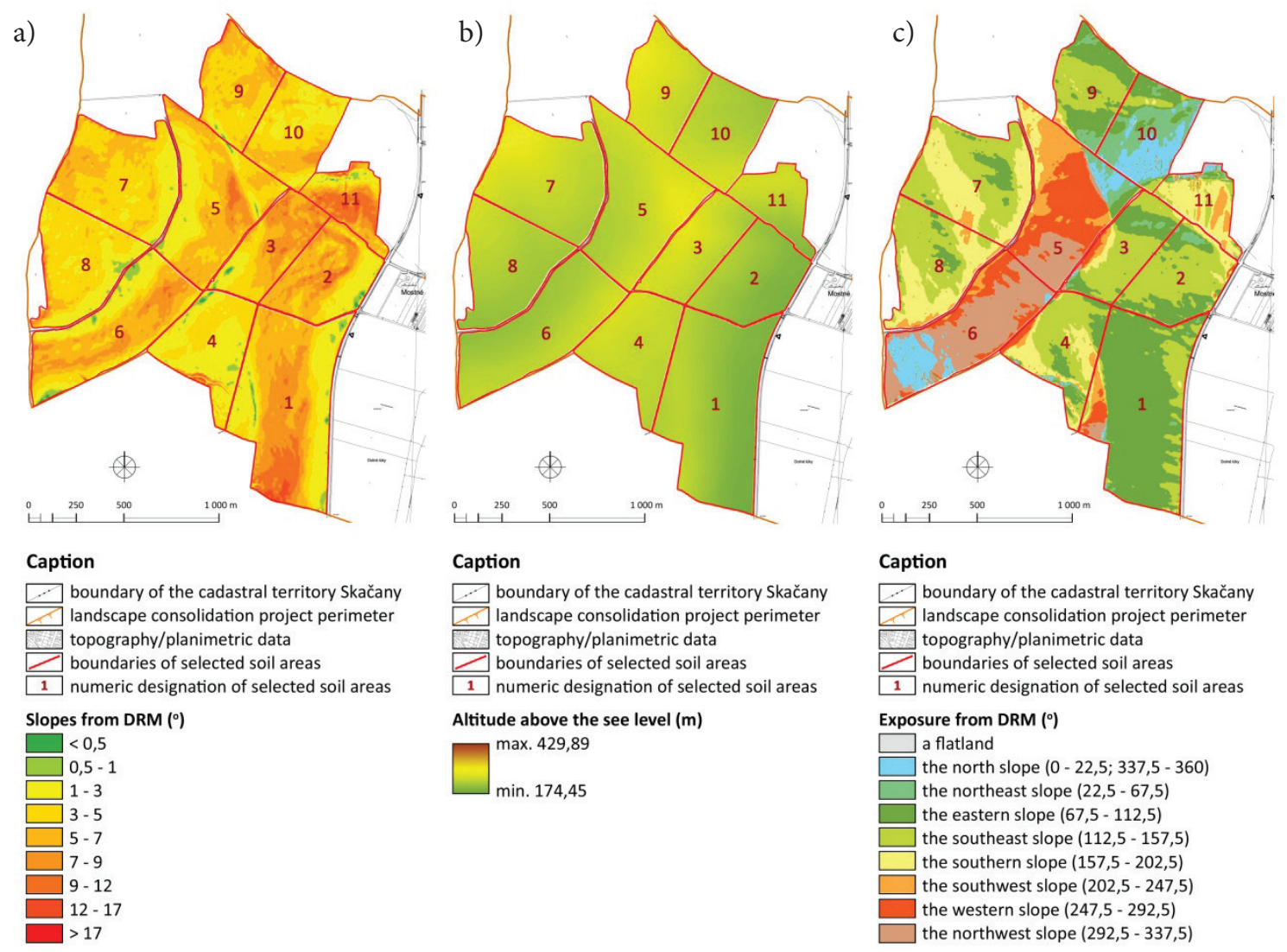

Figure 2. a) Slopes of the area, b) Altitude above the sea level, c) Exposure from DRM

brown soil, cambi-soil and rendzinas. According to the grain it has the largest representation of loam, prevailing soil without skeleton, deep soil. The agricultural soil of the addressed area is moderately productive on average.

SQEU use for land valuation is in clear need of informed discussion. The information and market prices are evidently incomparable. During a LC projects, it confuses owners and puts them at a disadvantage when receiving compensations for a net land loss. According to the municipality mayor of the model territory, average market price is about $3500 €$ per hectare $\left(10000 \mathrm{~m}^{2}\right)$, i.e. more as twice as much as the official $(1470 €)$ one. If relevant market data were available, there certainly would be possibilities to adapt/calculate the information price.

\subsection{Calculation of areas of prices by the currently valid method}

Calculation of areas of prices was based on the intersection the SQEU areas and relevant land areas. It means the creation of surface areas, each respecting the borders of the SQEU area, taking into account the interface between agricultural and non-agricultural land. With this procedure, surface objects for the application of Decree No. 38/2005 Coll., which includes rates for agricultural and remaining soil, have been created. In our case the non-occurrence of any non-agricultural areas means that our areas of values are identical to the boundaries of the
SQEU areas trimmed only by the border of the territory of interest. An illustrative map of the areas of values created using the current methodology is presented in Figure 3.

\section{Results and discussion}

To illustrate the proposed procedure for determining the value of land, we selected intensively cultivated agricultural land, namely the soil unit 1 (Figure $4 \mathrm{a}, 454200 \mathrm{~m}^{2}$ ). 10 SQEU areas lie in this project unit. The unit price of the SQEU area ranges from 0.022 to $0.156 €$ per $\mathrm{m}^{2}$.

When discussing the proposal a requirement for the placement of two siblings plots (new plots labelled 1a and $1 b$ ), who were previously in mutual ownership, side by side as required by the law. In the project unit 1, two identical plots have been designed. The position of the new plots is situationally illustrated in Figure $4 \mathrm{~b}$ and, with the unit price, Figure 5.

The price of the plots $(1 \mathrm{~A}$ and $1 \mathrm{~B})$ is determined as the value of the SQEU areas found in the plots according to the procedure laid down by Decree No. 38/2005 Coll. The procedure is evident from Table 4.

\subsection{Methodology of the new valuation system}

The new land valuation method assumes only one area price for the projection unit. First, the base price is calculated as the arithmetic mean of the products of individual 

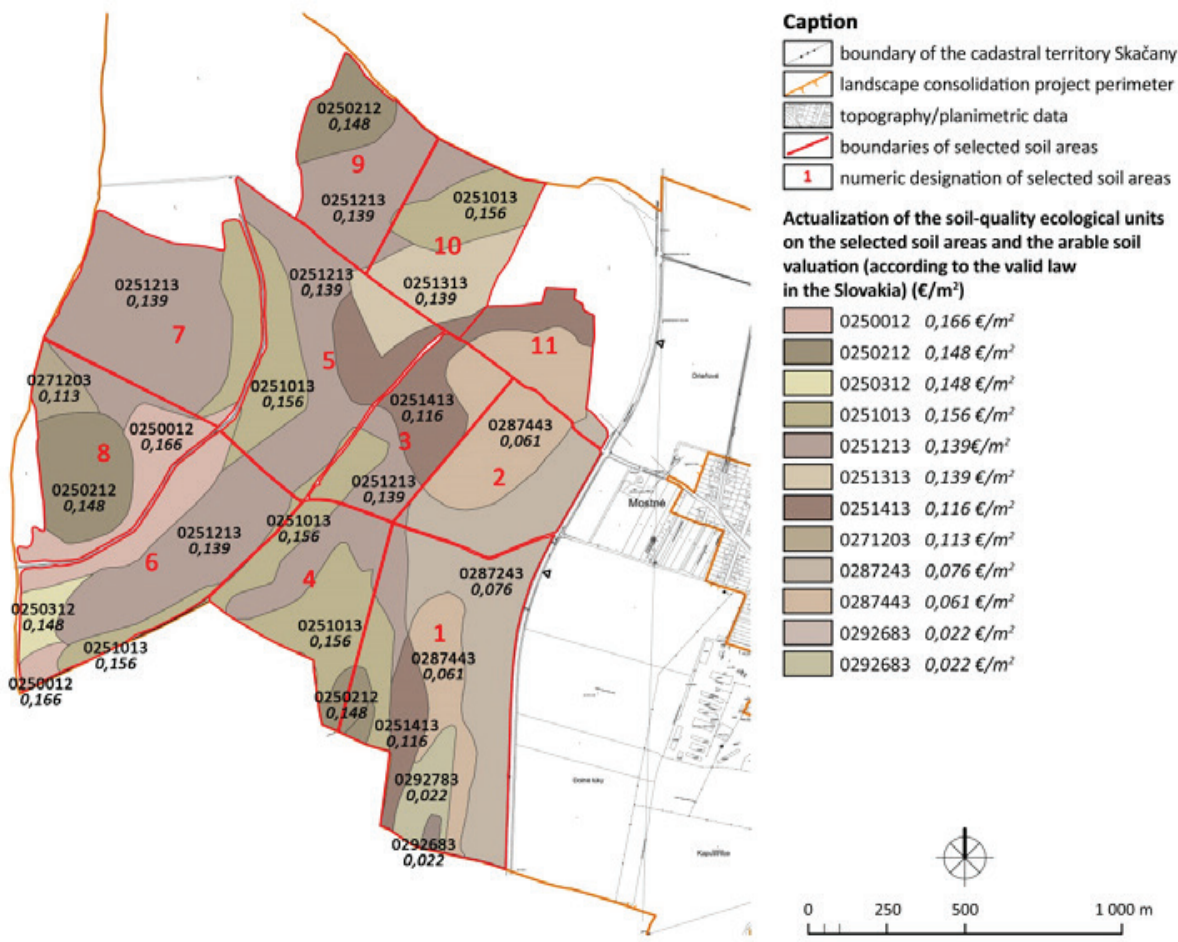

Figure 3. SQEU areas, SQEU unit price

a)

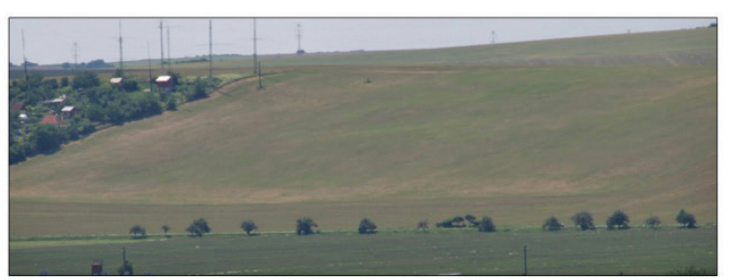

b)

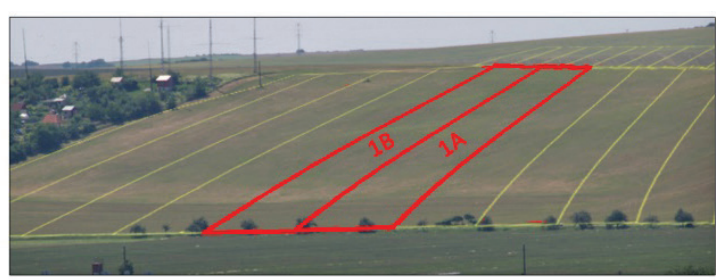

Figure 4. a) View of the soil unit 1, b) Situated owned land

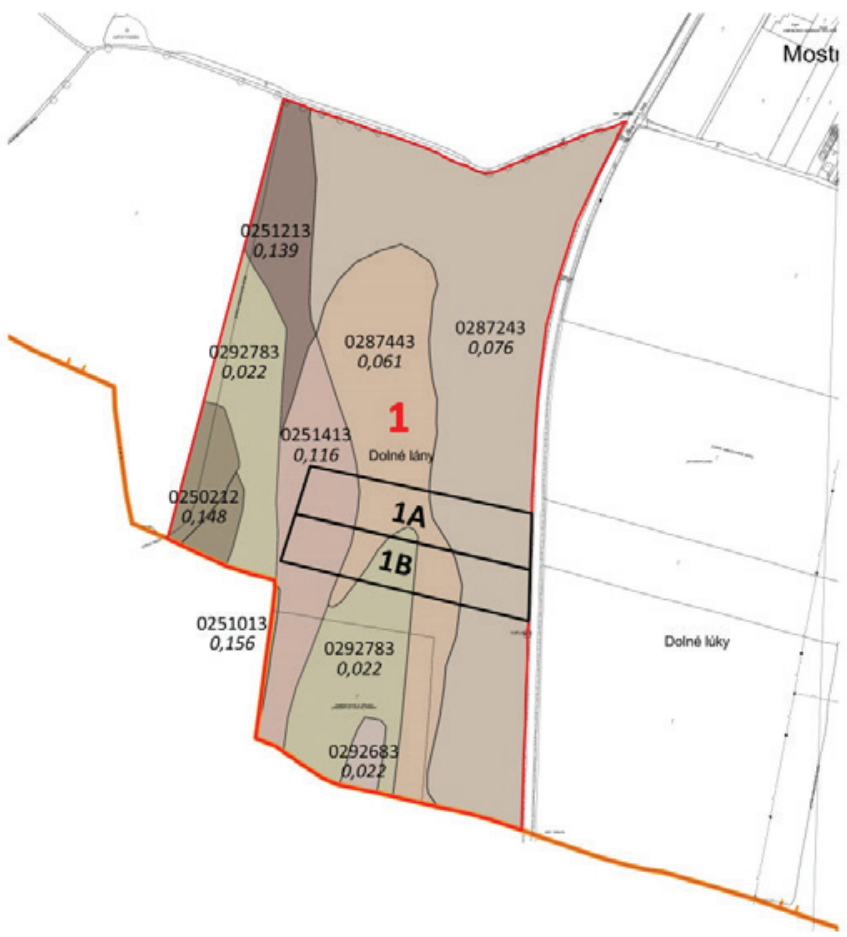



Actualization of the soil-quality ecological units on the selected soil areas and the arable soil valuation (according to the valid law in the Slovakia) $\left(\mathbf{E} / \mathrm{m}^{2}\right)$

प $02502120,148 \mathrm{\epsilon} / \mathrm{m}^{2}$

$02510130,156 € / m^{2}$

$02512130,139 € / \mathrm{m}^{2}$

$02514130,116 € / m^{2}$

$02872430,076 € / \mathrm{m}^{2}$

$02874430,061 \mathrm{\epsilon} / \mathrm{m}^{2}$

$02926830,022 \mathrm{c} / \mathrm{m}^{2}$

$02927830,022 \mathrm{\epsilon} / \mathrm{m}^{2}$

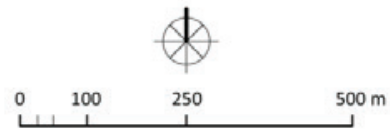

Figure 5. New plots allocation within a soil unit 
areas and price values of SQEU represented on the plot divided by the size of the projection unit (sum of all SQEU areas) (Equation (1)):

$$
H_{Z}=\frac{P_{1} h_{1}+P_{2} h_{2}+\ldots \ldots \ldots \ldots \ldots \ldots \ldots . .+P_{n} h_{n}}{P_{1}+P_{2}+\ldots \ldots \ldots \ldots \ldots \ldots . . .+P_{n}}
$$

where: $H_{z}$ - the average base price of the projection unit in $€ / \mathrm{m}^{2} ; P_{1}$ to $P_{n}$ - size of the area for relevant SQEU in $\mathrm{m}^{2} ; h_{1}$ to $h_{n}$ - price of the SQEU according to the Decree No. $38 / 2005$ Coll. in $€ / \mathrm{m}^{2}$; $n$ - count of SQEU areas within the projection unit.

The base price $\left(\mathrm{H}_{\mathrm{z}}\right)$, however, does not reflect the target value to which we want to arrive, as it represents only the adjusted value according to SQEU. Regarding the area of interest (projection unit) there are multiple factors that can influence the price of the plot. Long term practical experience of authors when dealing with owners in LC clearly shows that they value the locality the most as they know the prospective state of municipal planning and do not want to be relocated from the lucrative sites. In the second place, they value the historical context of the land; they remember well the sites that for some reason (based on the experience of many generations) make the land for the owners/inhabitants more lucrative. The levels and values of factors introduced below also reflect the usual minimal expectations of owners in relation to what they consider as more valuable. The levels and values could eventually be adapted to a particular situation based on a consensus of all owners (e.g. by a survey) or by an expert estimate calculated from relevant market price data if available in substantial amount. For simplification and transparency in setting the price of plots we introduced two basic factors: the $F_{R}$ (development factor) and $F_{M}$ (local factors), which may include other subsets of effects. The factors will act as multiplication coefficients for the $\mathrm{H}_{\mathrm{z}}$ value. These factors are a simplified analogy (to a certain degree) of the location differentiation method according to the decree No. 254/2010 Coll., and are, in our opinion, sufficient for the purposes of LC projects.

The first factor, $F_{R}$ - the development factor, is a multiplication coefficient based on the future prospects of the municipality land development. This factor "of the future" includes a land plan of the municipality if any, land reserves for individual housing construction, cultural and leisure as well as resting/recreational facilities and other investment intentions in the municipality. Limits of the development factor are defined to be from the interval of 1.05 to 1.25 in increments of 0.05 . The characteristic of the coefficient is illustrative. The final value of the development factor for each projection unit is to be determined after a discussion with the board of the association of participants in the LC on the designer's proposal in cooperation with the administration. The values of the development factor are shown in Table 1.

The second factor, the factor of local conditions $-\mathrm{F}_{\mathrm{M}}$, represents a set of impacts resulting from historical, local, natural and social contexts affecting the value of the plots. The factor is based on the knowledge of local residents in
Table 1. Values of the development factor $F_{R}$

\begin{tabular}{|c|l|}
\hline $\begin{array}{c}\text { Value of the } \\
\text { development } \\
\text { factor } \mathrm{F}_{\mathrm{R}}\end{array}$ & \multicolumn{1}{|c|}{ Characteristics } \\
\hline 1.05 & Territories for recreation and leisure \\
\hline 1.10 & Industrial construction in the medium term \\
\hline 1.15 & $\begin{array}{l}\text { Individual housing construction in the } \\
\text { medium term }\end{array}$ \\
\hline 1.20 & Industrial construction to 5 years \\
\hline 1.25 & Individual housing construction to 5 years \\
\hline
\end{tabular}

Table 2. Values of the local conditions factor $F_{M}$

\begin{tabular}{|c|l|}
\hline $\begin{array}{c}\text { Value of } \\
\text { the local } \\
\text { conditions } \\
\text { factor } \mathrm{F}_{\mathrm{M}}\end{array}$ & \multicolumn{1}{|c|}{ Characteristics } \\
\hline 1.05 & $\begin{array}{l}\text { Soil fertility according to local knowledge and } \\
\text { experience, which is not based on SQEU data }\end{array}$ \\
\hline 1.10 & $\begin{array}{l}\text { Socio-historical lucrativeness of the area based } \\
\text { on local conditions }\end{array}$ \\
\hline 1.15 & $\begin{array}{l}\text { Lucrativeness in terms of accessibility, family } \\
\text { relationships, and other local factors }\end{array}$ \\
\hline
\end{tabular}

the area of interest. Limits of the development factor are defined to be from the interval of 1.05 to 1.15 in increments of 0.05 . The value of the determined coefficient is to be determined by the board of the association of participants in the LC based on knowledge of the area and its territorial-historical and social contexts. The values of factor of local conditions are shown in Table 2.

Values of the $F_{R}$ and $F_{M}$ factors are determined for each projection unit. Multiple values of $F_{R}$ and $F_{M}$ factors within the projection unit are not allowed.

\subsection{Illustration of the new approach}

The first step is to determine the average base price of the project unit in $€ / \mathrm{m}^{2}$. The calculation procedure is schematically shown in Table 3. Example calculation is given for the soil unit 1; other soil units have been processed in the same way.

Thus, one price area for the entire project unit has been created while taking into account all the legal criteria for determining price maps for LC purposes. Next step of is presented for two situations:

1) Site in an agricultural area, without plans for construction/development or other functional use (e.g. without applications of factors); the valuation will use the average base price of the project unit in $€ / \mathrm{m}^{2}$ only.

2) Site situated in a territory with assumed increased demand for non-agricultural use (with the application of factors). In terms of municipality development, the potential recreational use of the soil unit 11 is being considered (i.e. with development factor $\left.F_{R}=1.05\right)$. Soil unit 1 is considered more valuable because of accessibility (i.e. with factor of local conditions $\mathrm{F}_{\mathrm{M}}=1.15$ ). 
The value of a project unit in Table 4 presents a single by weighted average determined number, which is the basis for the valuation of all the plots placed in individual soil units for cases where the plots are not lucrative in terms of possible development or local conditions. The final price of a soil unit is the application of factors that also influence the price of plots within in the same way. To compare the two procedures, we have created Figure 6, showing overlay of areas of prices determined by both methods.

Using the example of the placement of the plots of two siblings (also taking into account the significance of the location of the site for the future development of the area or lucrativeness in terms of access), same size and price of plots was reached using the proposed procedure. Both plots are evaluated equally by the single price area of the project unit. Without factors, the official price for the equally sized plots would be $2268 €$ (Table 5). With factors, the price for both brothers is $2676 €$.

Our demonstration is not the only type of situation where a small shift of plot causes a large change in its price. It is a common case that within the commenting process or due to an update of the original and new state based on the received documents, it is necessary to par- tially shift a land plot. Illustrated situation would mean shifting of the plot by its entire width.

Benefits of the proposed procedure can be seen especially in A) simplified design of land plots within each projection unit in terms of the price criteria, B) territorial differentiation according to future development as well as historical and social influences, C) involvement of owners and their local knowledge in plots valuation through the association of participants in the LC, D) application of multicriteria methods in determining the value of the original and new plots, E) creation of a set of assessment parameters with the aim of highlighting or suppressing some aspects, enhancing or restricting the view of the given evaluation system of the soil according to specific needs, G) formation of a "classification system" for evaluating original and new plots, $\mathrm{H}$ ) creating a modifiable, expandable and integrable reference implementation of examined procedures of plots valuation.

Price map of plots based only on the boundaries of the SQEU areas and types of plots causes problems when determining the relative prices of new plots within the proposed projection units. Figure 3 shows that in many cases, neighboring areas have more than twice the difference in value, causing problems when designing two neighboring

Table 3. Average base price of a project unit (presentation of example implemented for Soil Unit 1)

\begin{tabular}{|c|c|c|c|c|c|c|}
\hline $\begin{array}{l}\text { Project unit } \\
\text { identification }\end{array}$ & $\begin{array}{l}\text { SQEU codes for } \\
\text { the project unit }\end{array}$ & $\begin{array}{l}\text { SQEU area for the } \\
\text { project unit }\left[\mathrm{m}^{2}\right]\end{array}$ & $\begin{array}{l}\text { SQEU unit } \\
\text { value }\left[€ . \mathrm{m}^{-2}\right]\end{array}$ & $\begin{array}{l}\text { SQEU value for } \\
\text { the project unit }[€]\end{array}$ & $\begin{array}{l}\text { Price of the } \\
\text { project unit }[€]\end{array}$ & $\begin{array}{c}\text { Average base price } \\
\text { of the project } \\
\text { unit }\left[€ / \mathrm{m}^{2}\right]\end{array}$ \\
\hline \multirow[t]{10}{*}{1} & 0251013 & 1323 & 0.16 & 206 & \multirow[t]{10}{*}{38298} & \multirow[t]{10}{*}{0.084} \\
\hline & 0251413 & 46480 & 0.12 & 5392 & & \\
\hline & 0251013 & 34121 & 0.16 & 5323 & & \\
\hline & 0251213 & 28005 & 0.14 & 3893 & & \\
\hline & 0287243 & 191382 & 0.08 & 14545 & & \\
\hline & 0287443 & 85492 & 0.06 & 5215 & & \\
\hline & 0292783 & 44270 & 0.02 & 974 & & \\
\hline & 0250212 & 6052 & 0.15 & 896 & & \\
\hline & 0250212 & 11744 & 0.15 & 1738 & & \\
\hline & 0292683 & 5307 & 0.02 & 117 & & \\
\hline
\end{tabular}

Table 4. Calculation of the final price of the soil units by the proposed procedure

\begin{tabular}{|c|c|c|c|c|c|c|}
\hline Projected unit & $\begin{array}{c}\text { Product of value } \\
\text { and size }\end{array}$ & Size $\left[\mathrm{m}^{2}\right]$ & $\begin{array}{c}\text { Value of projection } \\
\text { unit }\left[€ / \mathrm{m}^{2}\right] \\
\text { Case }(1)\end{array}$ & $\begin{array}{c}\text { Local } \\
\text { Conditions } \\
\text { Factor } \mathrm{F}_{\mathrm{M}}\end{array}$ & $\begin{array}{c}\text { Development } \\
\text { Factor } \mathrm{F}_{\mathrm{R}}\end{array}$ & $\begin{array}{c}\text { Final price of soil } \\
\text { unit }\left[€ / \mathrm{m}^{2}\right] \\
\text { Case }(2)\end{array}$ \\
\hline 1 & 38298.33709 & 454176.75 & 0.084 & 1.15 & 1 & 0.097 \\
\hline 2 & 13936.66329 & 201856.98 & 0.069 & 1 & 1 & 0.069 \\
\hline 3 & 20094.56343 & 169564.33 & 0.119 & 1 & 1 & 0.119 \\
\hline 4 & 30983.24784 & 206661.49 & 0.150 & 1 & 1 & 0.150 \\
\hline 5 & 45986.67923 & 328857.02 & 0.140 & 1 & 1 & 0.140 \\
\hline 6 & 45940.27375 & 309356.98 & 0.149 & 1 & 1 & 0.149 \\
\hline 7 & 42702.38322 & 299814.69 & 0.142 & 1 & 1 & 0.142 \\
\hline 8 & 35528.40830 & 240305.94 & 0.148 & 1 & & 1 \\
\hline 10 & 25754.25591 & 181244.54 & 0.142 & 1 & & 1 \\
\hline 11 & 28170.12636 & 194186.64 & 0.145 & 1 & 1.05 & 0.142 \\
\hline
\end{tabular}



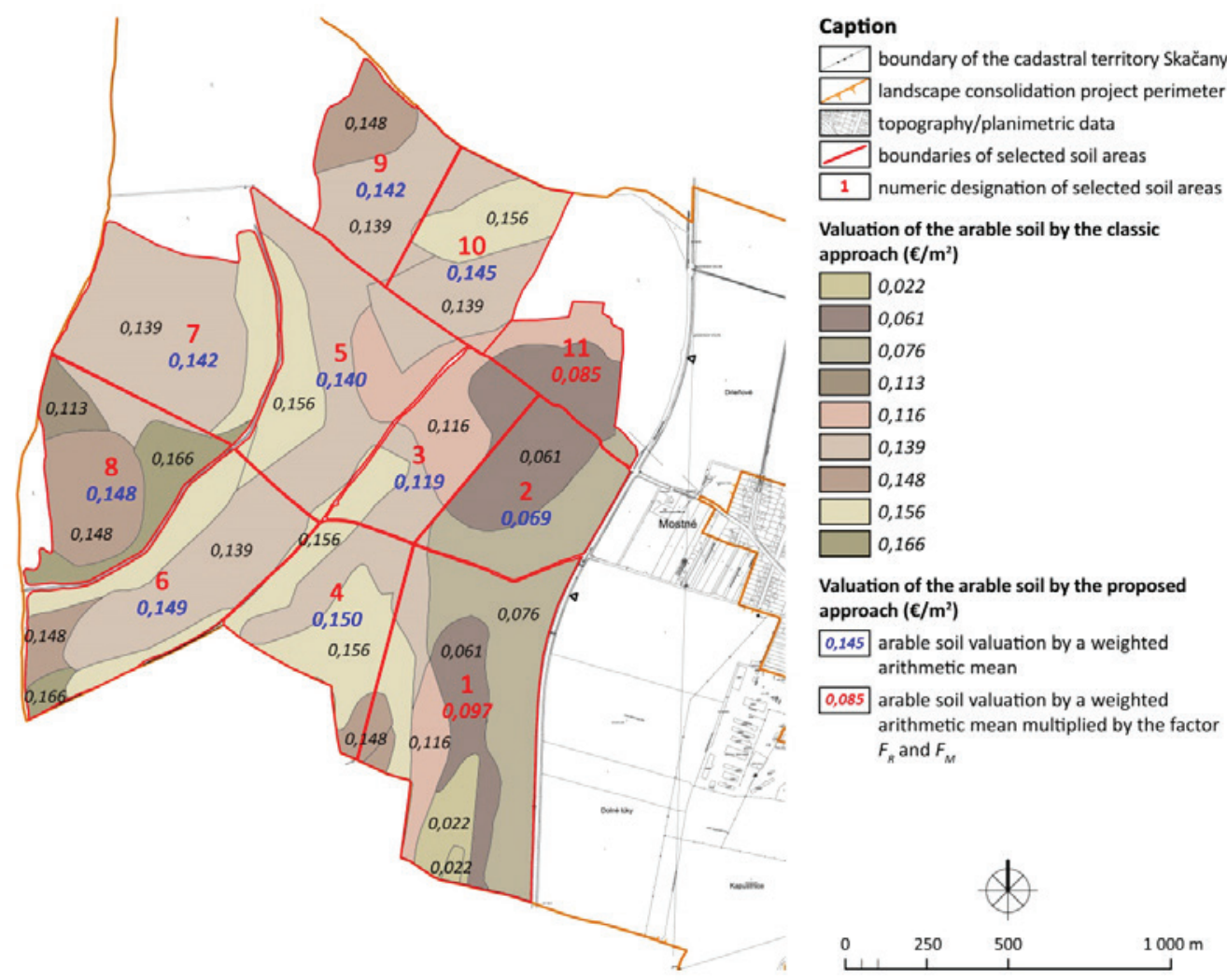

Figure 6. Valuation of project units

Table 5. Example calculation of the modified plot prices

\begin{tabular}{|c|c|c|c|c|c|c|}
\hline $\begin{array}{c}\text { New plot } \\
\text { identification }\end{array}$ & $\begin{array}{c}\text { New plot area } \\
{\left[\mathrm{m}^{2}\right]}\end{array}$ & $\begin{array}{c}\text { Average base value } \\
\text { of the project unit } \\
{\left[€ / \mathrm{m}^{2}\right]}\end{array}$ & $\begin{array}{c}\text { Modified plot } \\
\text { value }[€] \\
\text { Case }(\mathrm{a})\end{array}$ & $\begin{array}{c}\text { Development } \\
\text { factor } \\
\mathrm{F}_{\mathrm{R}}\end{array}$ & $\begin{array}{c}\text { Modified } \\
\text { average value } \\
{\left[€ / \mathrm{m}^{2}\right]}\end{array}$ & $\begin{array}{c}\text { Modified plot } \\
\text { value }[€] \\
\text { Case }(\mathrm{b})\end{array}$ \\
\hline $1 \mathrm{~B}$ & 27700 & 0.084 & 2268 & 1.15 & 0.097 & 2676 \\
\hline $1 \mathrm{~A}$ & 27700 & 0.084 & 2268 & 1.15 & 0.097 & 2676 \\
\hline
\end{tabular}

plots in virtually homogenous soil units. This enormously complicates the placement of new plots in compliance with legal criteria. LC project designer rearranges plots using the spatial and functional arrangement of the country (optimal arrangement of roads, water management, erosion and environmental measures) using proposed project units and discussion of the proposal of the new plots with the owners. Project units are areas of agricultural soil intended for the subsequent parceling of new plots and are created so that new plots are earmarked within them for future usage. They may have a different shape and size, and according to circumstances, the entire unit becomes a single individual new plot, or is divided into several new plots. An LC project designer has to identify the basic parameters for the valuation of existing and new plots (Muchová et al., 2009) already at this stage. Placement of the plots into proposed projection units is a subject of an agreement with the owner after a discussion. The boundaries of the areas of prices enter into this process as an alien element with a fully different course for boundaries (e.g. following contour lines in many cases) that is also of major importance for the design of a new plot. A logical consequence of the above mentioned facts is the need for association of the boundaries of these control elements for projecting. A sensitive approach is necessary in landscape planning stage for projected units bearing in mind that areas with homogeneous value are created. Here, it would be necessary to modify the customary sequence of LC project stages, because if one wants to identify the boundaries of the areas of prices with the projection units it must do so before determining the price of the plots before redistribution.

Our reflection on the need to change procedures during the final price adjustment of new plots was motivated by known problems in satisfying the demands of the plot owners. Presented new possibilities for addressing this difficult task respect given requirements of the law while also offer a more objective approach to the owner. It can be expected that this contribution will be a stimulus to call for a broader expert discussion that would develop and possibly augment the outlined solution. The proposal could also generate suitable material for the production of comparative studies that are rare, not only in Slovak conditions, see e.g. Jahanshiri, Buyong, and Shariff (2011), Demetriou (2016). 


\section{Conclusions}

In this contribution the authors focused on the possibility of reevaluating the current procedure for the valuation of plots and finding a new approach that would more realistically account for the benefits of a particular location. Authors proposed to determine official (information) prices with a multicriteria evaluation that includes areas of the spatial distribution of soil-quality ecological units (SQEU) through a single price area for the projection unit as well as a development factor and local factor. Specific procedures for the evaluation of plots on agricultural soil in LC are illustrated by an example from the cadastral area of Skačany (in northwestern Slovakia). The multicriteria view and factors allow fine-tuning to a specific situation, while maintaining transparency and compliance with legislative requirements eliminate the disregard for actual value of the plots and large differences in information price levels in the neighborhood. The proposal maintains the principle of price maps and does not require any changes in the methodology of LC, with the exception of placing the association of boundaries of areas of values with projection units before determining prices of plots prior to redistribution. In this way, however, one avoids the disproportions caused by SQEU borders within the soil units. Authors consider the new approach to be fairer to owners and easier to implement in LC projects while in compliance with proportionality criteria.

\section{Acknowledgements}

This work was supported by the Ministry of Education of the Slovak Republic and of Slovak Academy of Science [grants number VEGA 1/0673/16 and KEGA 008SPU-4/2017].

\section{References}

Branković, S., Parezanović, L., \& Simović, D. (2015). Land consolidation appraisal of agricultural land in the GIS environment. Geodetski Vestnik, 59(02), 320-334.

https://doi.org/10.15292/geodetski-vestnik.2015.02.320-334

Buday, Š. (2012). Determining the value of land plots. Training for the confirmatory test for the holders of the certificate for the design of land consolidation. Bratislava: Ministry of Agriculture and Rural Development of the Slovak Republic (in Slovak).

Buday, Š., \& Vilček, J. (2013). Categorization and evaluation of agricultural land in Slovakia. Brno: Mendel University in Brno (in Slovak).

Bujnovský, R., Balkovič, J., Barančíková, G., \& Vilček, J. (2009). Assessment and valuation of ecological functions of agricultural soils in Slovakia. Bratislava: Soil Science and Conservation Research Institute in Bratislava (in Slovak).

Demetriou, D. (2016). The assessment of land valuation in land consolidation schemes: the need for a new land valuation framework. Land Use Policy, 54, 487-498. https://doi.org/10.1016/j.landusepol.2016.03.008

Eurosense. (2014). The orthophotomap of the cadastral territory Skačany. Eurosense s. r. o. (Slovakia), Bratislava. Retrieved from http://www.eurosense.com/documents/about-us/contact/slovakia.xml?lang=en-gb

FAO. (2003). The design of land consolidation pilot projects in Central and Eastern Europe. Rome: FAO.
Grausová, G., \& Buday, M. (2016). Transactions with agricultural land in 2014 and the impact of land consolidation on land market. Economics of Agriculture, 16(2), 22-43 (in Slovak).

Hartvigsen, M. (2014). Land reform and land fragmentation in Central and Eastern Europe. Land Use Policy, 36, 330-341. https://doi.org/10.1016/j.landusepol.2013.08.016

Jahanshiri, E., Buyong, T., \& Shariff, A. R. M. (2011). A review of property mass valuation models. Pertanika Journal of Science and Technology, 19(spec. issue), 23-30.

Kertscher, D. (2003, April). The German digital purchase price collection - maintenance, use, results. FIG Working Week. Paris, FR.

Konc, L. (2012). Determination of the value of plots in land consolidation using multicriteria approach. The Slovak University of Agriculture in Nitra (in Slovak).

Lisec, A., \& Pintar, M. (2005). Conservation of natural ecosystems by land consolidation in the rural landscape. Acta Agriculturae Slovenica, 85, 73-82.

Lisec, A., Primožič, T., Ferlan, M., Šumrada, R., \& Drobne, S. (2014). Land owners' perception of land consolidation and their satisfaction with the results - Slovenian experiences. Land Use Policy, 38, 550-563.

https://doi.org/10.1016/j.landusepol.2014.01.003

Muchová, Z., Stredanská, A., \& Konc, L. (2014). A proposal for an innovative approach to the determination of the value of plots in the comprehensive land consolidation projects. Economics of Agriculture, 14(2), 1-12 (in Slovak).

Muchová, Z., Vanek, J., Halaj, P., Hrnčiarová, T., Konc, L., Raškovič, V., Stred’anská, A., Šimonides, I., \& Vašek, A. (2009). Methodical standards for the design of land consolidation. Slovak University of Agriculture in Nitra \& Ministry of Agriculture and Rural Development of the Slovak Republic. Nitra: Garmond (in Slovak).

National Council of the Slovak Republic. (1991). Act No. 330/1991 Coll. on land consolidation, arrangements of land ownership, land offices, land fund and about land associations, as amended. Wolters Kluwer SR s. r. o., Bratislava. Retrieved from https:// www.noveaspi.sk/products/lawText/1/39357/1/2 (in Slovak).

National Council of the Slovak Republic. (2005). Decree No. 38/2005 Coll. on the determination of the value of land and crops for the purpose of land consolidation. Wolters Kluwer SR s. r. o., Bratislava. Retrieved from https://www.noveaspi. sk/products/lawText/1/59744/1/2 (in Slovak).

National Council of the Slovak Republic. (2010). Decree No. 254/2010 on the determination of the general value of a property, as amended. Wolters Kluwer SR s. r. o., Bratislava. Retrieved from https://www.noveaspi.sk/products/lawText/1/71193/1/2 (in Slovak).

Stredanská, A., Muchová, Z., \& Konc, L. (2013). Valuation and the price of soil in land consolidation. Nitra: Publishing Center of the Slovak University of agriculture in Nitra (in Slovak).

Tanentzap, A. J., Lamb, A., Walker, S., \& Farmer, A. (2015). Resolving conflicts between agriculture and the natural environment. PLoS Biology, 13(9), 1-13. https://doi.org/10.1371/journal.pbio.1002242

Vanek, J., Hudecová, L., Hatalová, M., Hurníková, I., Navrátilová, D., Uhlík, V., Urban, J., \& Vašek, A. (2008). Methodological instructions of geodetic activities for land consolidation project. Ministry of Agriculture and Rural Development of the Slovak Republic \& Geodesy, Cartography and Cadastre Authority of Slovak Republic, Bratislava (in Slovak).

Yomralioglu, T., Nisanci, R., \& Yildirim, V. (2007, May). An implementation of nominal asset based land readjustment. FIG Working Week. Hong Kong SAR, China.

Yomralioglu, T., \& Nisanci, R. (2004, May). Nominal asset land valuation technique by GIS. FIG Working Week. Athens, Greece. 